\title{
高齢世帯の住宅資産保有に関する階層分析 ELDERLY HOUSEHOLDS AND THE STRATIFICATION OF HOUSING ASSET ACCUMULATION
}

\author{
平山洋介* \\ Yosuke HIRAYAMA
}

\begin{abstract}
This paper explores the stratification of residential property assets among increasing numbers of older households. Empirical evidence was obtained from re-calculating the micro-data from the National Survey of Family Income and Expenditure. The paper looks at the tendency of economic conditions relating to home ownership to become more stratified. Elderly people with lower incomes tend to live in owner-occupied houses with lower property values while those with higher incomes own houses with higher property values. Moreover, higher-income elderly households more often possess a second property that produces rental incomes. The pronounced disparity of home ownership conditions among older people will arguably create destabilizing socio-economic effects.
\end{abstract}

Keywords : older people, home-ownership, housing assets, additional housing, housing policy 高齢者, 住宅所有, 住宅資産, 付加住宅, 住宅政策

\section{1. 目的と方法}

本稿は、高齢世帯の住宅資産保有を対象とし、その階層化の実態 を明らかにしようとするものである。ここでの高齢世帯とは、65 歳 以上の人員を含む世帯を意味し、住宅資産とは、住宅建築だけでは なく、それに土地を合わせた居住用不動産全体の資産を指す。

高齢世帯の大半は持家世帯を形成し、住宅資産を保有してきた。 高齢者にとって、住宅所有は居住の安定をもたらすと同時に、暮ら しの経済基盤を形成するうえで、重要な役割を果たしている注1)。高 齢期に入った世帯は所得の低下を経験する。しかし、持家に住む高 齢者の多くは、住宅ローンの返済を終えていることから、その住居 費負担は小さい。住宅所有は不動産資産の形成に結びつく。高齢者 の資産全体のなかで、持家資産は大きな位置を占める。

しかし、高齢世帯の住宅資産保有は一様ではない。多数の高齢者 が住宅を所有する一方、持家取得に到達せず、借家に住む高齢者が 存在する。高齢期の持家世帯のなかでは、保有する住宅資産の規模 に大きな差がある。高齢世帯の住宅資産保有の実態を知るには、そ の平均像だけではなく、階層性を捉えることが不可欠の作業になる 本研究では、2004 年の全国消費実態調查のミクロデータ（個票） を独自に集計し、高齢世帯が保有する住宅資産に関して統計分析を 行った。住宅資産の多くは高齢期の世帯に集中している実態がある。
同調查によれば、総世帯数に対する高齢世帯数の割合は $38.4 \%$ であ る。そして、全年齢層の世帯が保有する住宅資産の総額のうち、高 齢世帯の住宅資産額が占める割合は $51.9 \%$ に及ぶ注2)。この状況を前 提とし、高齢世帯が蓄積した住宅資産の内容を、とくに階層性に着 目して把握することが本稿の主眼である。

住宅問題研究の分野では、住まいの条件を示す指標として住宅所 有形態を重視する。本研究の分析手法上の特徵は、この住宅所有形 態における持家を「持家（付加無し）」と「持家（付加有り）」に区 分した点である。「持家（付加有り）」世帯とは、その世帯が住んで いる「現住宅」だけではなく、それとは別の住宅を「付加住宅」と して所有し、複数の住宅を保有する世帯、「持家（付加無し）」世帯 とは、所有している住宅が「現住宅」のみの世帯と定義される。高 齢世帯のグループでは、現住宅だけを所有する世帯が主流を占める と同時に、現住宅と付加住宅の双方を所有する世帯が無視しえない 比重を示す。付加住宅を保有する持家世帯では、それを貸貸住宅と して運用し、家顀収入を得るケースがある。この場合の付加住宅は 収入源としての機能をもつ。本稿を通じて示すように、高齢の持家 世帯は均質のグループではなく、持家（付加無し）世帯と持家（付 加有り）世帯は異なる性質を有している。持家率の高い高齢世帯に 関して、その住宅資産保有の階層性をみようとするとき、持家世帯

\footnotetext{
$*$ 神戸大学大学院人間発達環境学研究科 教授・学博

Prof., Graduate School of Human Development and Environment, Kobe University, Ph. D.
} 
全体を一括して扱うのではなく、持家（付加無し）と持家（付加有 り）に分けて観察することが、一つの有効なアプローチになる。

前稿では、住宅資産形成の状況を全年齢層に関して分析し、その 結果の一つとして、資産保有実態が所得階層によって異なることを 示した ${ }^{32}$ 。これに対し、本稿では、住宅資産の多い高齢世帯に焦点 を合わせ、持家（付加無し）と持家（付加有り）を区分するという 新たな視点から資産保有の階層性を分析した。

全国消費実態調査のミクロデータは一橋大学経済研究所附属社 会科学統計情報センターが調査対象者を特定できないように秘匿 処理を施し、約 8 割の抽出を行ったうえで貸し出していたものであ る ${ }^{\text {注 }}{ }^{4)}$ 。同調査は市区町村の人口規模等によって調查対象住戸の抽出 率が調查区ごとに異なる。このため同調査の結果の集計では乗率 (抽出率の逆数) が用いられる。ミクロデータの抽出では、秘匿処 理の観点から乗率の階級区分が設定され、都道府県別・乗数階級区 分別、及び 2 人以上・単身世帯別に乗率の確率比例抽出によって約 8 割の標本が選ばれる。抽出された個別データには都道府県別・階 級区分別の乗率の平均值が与えられている。本研究では、この乗率 平均值を用いて集計を行った。

以下では、(1)高齢世帯の住宅所有形態をみたうえで（２章）、(2) 住宅資産保有の階層性（3 章)、(3)付加住宅による家貨収入 (4 章) を分析し、(4)最後に、分析結果の住宅政策に対する含意を考察する ( 5 章)。高齢者の住宅資産に関わる研究領域では、リバースモー ゲージなどの不動産活用、及び遺産相続に対する関心が高い注5)。高 齢の持家世帯が多量の住宅資産をもつことから、それをどのように 活用するのか、その相続はどのような役割を果たすのか、という問 題をめぐって議論が重ねられた。これらの議論をより適切に進める には、高齢者の住宅資産保有の階層性を把握する必要がある。住宅 資産保有が不均質であるとすれば、不動産活用と相続の内容もまた 不均質にならざるをえない。しかし、高齢世帯の住宅資産の階層性 は明らかになっていない注6)。その主な要因は、大規模調查にもとづ く公的統計の不在である。全国消費実態調查は住宅資産の状況を調 查項目に含めている。しかし、住宅資産に関する公表集計は乏しく、 その階層化の実態はほとんど不明のままであった。これに対し、本 研究では同調查のミクロデータの独自集計によって住宅資産の分 析を可能にした。

\section{2. 高齢世帯の住宅所有形態}

ここでは、高齢世帯の住まいの所有形態を観察する。表 1 は、住 宅所有形態に関して、高齢世帯とその他世帯を比較したものである 注7)。その他世帯とは、高齢世帯以外の 65 歳以上人員を含まない世 帯である。このデータが示すように、その他世帯では持家率が $61.3 \%$ であるのに対し、高齢世帯の持家率は $87.6 \%$ ときわめて高い。持家 のグループを持家（付加無し）と持家（付加有り）に分け、それぞ れの割合をみると、その他世帯では $52.8 \%$ と $8.5 \%$ 、高齢世帯では $68.8 \%$ と $18.8 \%$ であった。持家（付加無し）と持家（付加有り）の 双方ともに高齢世帯においてより多い。高齢世帯では、自己居住の 現住宅のみを所有する世帯が多く、7 割近くという高い比率を示す 一方、付加住宅を所有する持家世帯が 2 割近くを占めている。借家 世帯の比率は、その他世帯での $38.7 \%$ に比べ、高齢世帯では $12.4 \%$ と少ない。借家の高齢世帯のなかでは、民営借家（6.9\%) が最も多
く、これに次いで公営借家 $(3.9 \%)$ が多い。借家世帯のグループは 付加住宅を所有する世帯を含む。しかし、付加住宅をもつ借家世帯 はきわめて少なく、その他世帯では $3.9 \%$ 、高齢世帯では $0.8 \%$ にす ぎない。

高齢世帯での持家（付加有り）世帯の割合を高める要因の一つは 住宅相続である 注 ${ }^{8}$ 。寿命の延びによって遺産相続の時期は遅れる傾 向にある。このため、子世代では、年齢が上昇し、自身の持家を取 得した後に親の住宅を相続し、複数の住宅の所有者になる、という パターンが増える。日本郵政公社郵政総合研究所（現財団法人ゆう ちょ財団）が 3127 世帯を対象として 2006 年に実施した「家計にお ける金融資産選択等に関する調查」によれば、14\%の世帯が居住用 不動産の相続を受けた経験をもつ。この比率は年齢が上がるほど増 え、世帯主 30 歳代での $2 \%$ 、40 歳代での $7 \%$ に比べ、50 歳代では $15 \% 、 60$ 歳以上では $20 \%$ であった注 9 。

次に、高齢世帯の基本属性を表す世帯収入と世帯類型をみる（図 1)。世帯年収では、300 万〜 700 万円の $44.5 \%$ において比率が高く なっているが、300 万円未満が 30.5\%を占めると同時に、700 万円 以上が $25.0 \%$ を示し、大きな幅が認められる。世帯類型では、同居

表 1 高龃世帯とその他世帯の住宅所有形態

\begin{tabular}{lcc}
\hline & $\begin{array}{c}\text { 高齢世帯 } \\
(\%)\end{array}$ & $\begin{array}{c}\text { その他世帯 } \\
(\%)\end{array}$ \\
\hline 持家 (付加無し) & 68.8 & 52.8 \\
持家 (付加有り) & 18.8 & 8.5 \\
民営借家 & 6.9 & 25.6 \\
公営借家 & 3.9 & 4.3 \\
公団・公社等借家 & 1.3 & 1.9 \\
給与住宅 & 0.4 & 6.9 \\
\hline
\end{tabular}

注）1）高齢世帯は65歳以上の世帯員を含む世帯、その他世帯は 65歳以上の世帯員を含まない世帯。

2）民営借家は借間を含む。

3 ）給与住宅は寮・寄宿舎を含む。4）不明を除く。

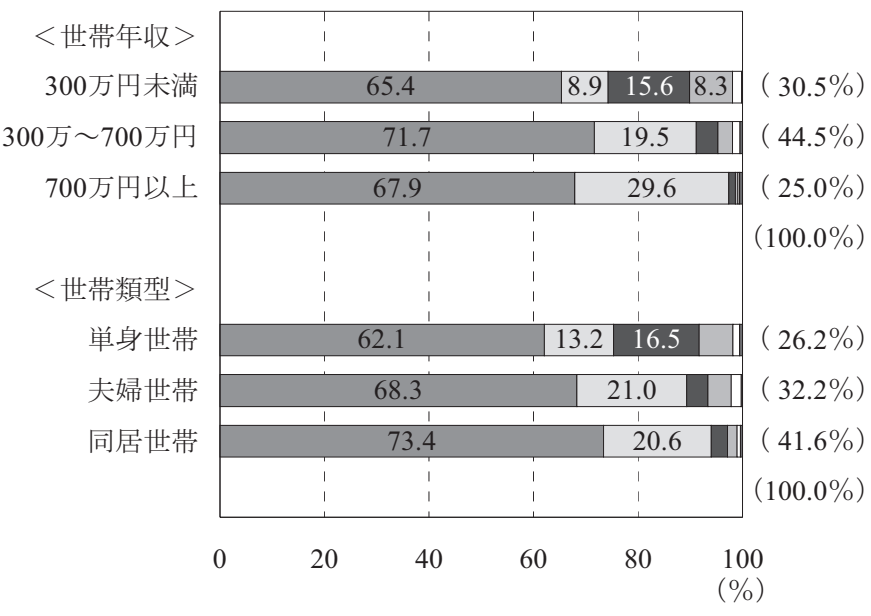

$\begin{array}{ll}\square \text { 持家(付加無し) } & \square \text { 持家(付加有り) } \quad \text { 民営借家 } \\ \square \text { 公営借家 } & \square \text { 公団·公社等借家 } \square \text { 給与住宅 }\end{array}$

注）1）65歳以上の世帯員を含む世帯について集計。

2 ）括弧内は、世帯年収別・世帯類型別世帯数の構成比。

3 ）民営借家は借間を含む。

4 ）給与住宅は寮・寄宿舎を含む。5）不明を除く。

図 1 世帯年収・世帯類型別高齢世帯の住宅所有形態 
世帯が $41.6 \%$ と最も多く、夫婦世帯は $32.2 \%$ 、単身世帯は $26.2 \%$ で あった。同居世帯の内訳では、既婚子と同居する世帯（23.5\%）が 多く、次いで未婚子と同居する世帯 $(13.4 \%)$ が多い。

世帯年収と住宅所有形態は明快に相関する（図 1 )。持家率は年 収が多いほど高く、年収 300 万円未満の世帯では $74.3 \%$ であるのに 対し、300 万〜 700 万円の世帯では 91.2\% と高く、700 万円以上の世 帯では $97.5 \%$ といっそう高い。年収 300 万円未満の世帯では、民営 借家が $15.6 \%$ と相対的に多い。年収の高いグループでは付加住宅を 所有する持家世帯がより多い。持家（付加有り）の比率は、年収 300 万円未満での $8.9 \%$ に対し、300 万〜 700 万円では 19.5\%、700 万円 以上では $29.6 \%$ を占める。高所得の世帯は住宅相続の機会をより多 くもち、また同時に、投資目的などから付加住宅を取得する場合が あるとみられる。

世帯類型と住宅所有形態の関係をみると（図 1 )、持家の割合は、 単身世帯での $75.3 \%$ に比べて、夫婦世帯では $89.3 \%$ 、同居世帯では $94.0 \%$ とより高い。同居世帯の持家は、親世代の所有、子世代の所 有、親子の共有など、所有の多様なパターンにもとづくと考えられ る。しかし、全国消費実態調查では、このパターンの構成は不明で ある。付加住宅を所有する持家世帯は、単身世帯では $13.2 \%$ あるる のに対し、夫婦世帯では $21.0 \%$ 、同居世帯では $20.6 \%$ と相対的に多 い。民営借家に住む世帯は、夫婦世帯と同居世帯ではきわめて少な い。これに比べ、単身世帯では民営借家率が 16.5\%を示す。単身世 帯のグループは配偶者との死別などによって単身化した世帯、配偶 者をもたないままで高齢化した世帯などを含む。前者のケースでは、 家族を形成していた時期に住宅を購入した世帯が多いのに対し、後 者のケースでは、持家を取得しなかった世帯の割合が高いと推察さ れ、それが単身世帯全体の持家率を低くする一因になっている注 ${ }^{10)}$ 。

\section{3. 住宅資産保有の階層性}

ここでは、高齢世帯の住宅資産保有が階層化している実態をみる。 全国消費実態調査では、住宅建築の資産額は総資産額（粗資産額） と純資産額の 2 種類の指標によって示される。総資産額は住宅の延 べ床面積に都道府県別・住宅の構造別 $1 \mathrm{~m}^{2}$ 当たり建築単価を乗じた 数值、純資産額は総資産額に住宅の構造別・建築時期別残価率を乗 じた数值である。ここでは残価率を考慮に入れた純資産額を使用寸 る。同調查公表集計の資産総額などの算出においても純資産額が使 われている注 11)

資産額の一世帯当たり平均值について、高齢世帯とその他世帯を 比較したものが表 2 である。このデータが示すように、高齢世帯で は資産規模が大きい。資産総額は、その他世帯では 2577 万円であ るのに対し、高齢世帯では 5058 万円に達し、両者には約 2 倍の差 がある。資産の内訳では、住宅資産が最も大きく、次いで金融資産 が多い。住宅資産は資産全体のなかで中心的な位置を占めている。 高齢世帯では、その他世帯に比較して、住宅資産と金融資産の双方 の規模が大きい。住宅資産額と金融資産額は、高齡世帯では 3332 万円と 1593 万円、その他世帯では 1927 万円と 509 万円であった。 高齢世帯が多量の住宅資産をもつ傾向は、その持家率の高さを反映 したものである。金融資産額は、貯蓄等現在高から負債現在高を差 し引いて算出される。負債の大半は住宅のための負債によって占め られ、それ以外の負債は小さい。高齢世帯では、貯蓄等が大きく
(1850 万円)、住宅関連の負債が小さいことから（195 万円）、金融 資産が多くなる。高齢世帯の住宅のための債務が少量であるのは、 住宅ローンの返済が終わった世帯が多いことを表している。後述の ように、持家の高齢世帯の 8 割強は住宅関連の負債をもっていない。 これに対し、その他世帯は、貯蓄等が少なく（1082 万円）、住宅の ための負債が大きいために（509 万円）、小規模な金融資産しかもっ ていない。その他世帯では、持家率が相対的に低い一方、持家を取 得した場合の住宅ローン債務が大きい。以上のように、資産状況に 関する高齢世帯の平均像を特徴づけるのは、多量の住宅資産、少量 の住宅関連の負債、及び多量の貯蓄、これらの結果としての大規模 な資産総量である。

しかし、高齢世帯のグループは均質ではない。高齢世帯が保有す る資産は階層性をもち、その一世帯当たり平均值は、住宅所有形態 に応じてきわだった違いをみせる（表 2 ）。借家世帯に比べて持家 世帯、持家 (付加無し) 世帯よりも持家 (付加有り) 世帯において、 資産規模がより大きい。資産総額は、借家での 1012 万円に比較し て、持家（付加無し）では 4327 万円と多く、持家（付加有り）で は 1 億 311 万円といっそう多い。持家（付加有り）世帯は、保有資 産がとくに多いという特性を有し、借家世帯に比較して約 10 倍、 持家（付加無し）世帯に比べて 2 倍以上の資産をもつ。資産の中心 である住宅資産の規模をみると、持家（付加無し）では 2645 万円 であるのに対し、持家（付加有り）では 7851 万円に達する。これ は、後述のように、持家（付加有り）世帯の現住宅資産額が持家（付 加無し）世帯のそれよりも大きく、そして、付加住宅の所有が持家 （付加有り）世帯の住宅資産をさらに増量するためである。借家世 帯の少量の住宅資産は、少数の世帯による付加住宅の所有を反映し たものである。金融資産額は、借家では784 万円であるのに対し、 持家（付加無し）では 1550 万円と高く、持家（付加有り）では 2270 万円とより高い。この違いの主な要因は、貯蓄等現在高の差である。 貯蓄等は、借家での 815 万円に比へ、持家（付加無し）では 1767 万円と多く、持家（付加有り）では 2818 万円とさらに多い。高龃

表 2 高齢世帯とその他世帯の資産額

\begin{tabular}{|c|c|c|c|c|c|}
\hline & \multicolumn{4}{|c|}{ 高齢世帯 } & \multirow{2}{*}{$\begin{array}{c}\text { その他 } \\
\text { 世帯 }\end{array}$} \\
\hline & $\begin{array}{c}\text { 持家 } \\
\text { (付加 } \\
\text { 無し) } \\
\text { (千円) }\end{array}$ & $\begin{array}{c}\text { 持家 } \\
\text { (付加 } \\
\text { 有り) } \\
\text { (千円) }\end{array}$ & (千円) & (千円) & \\
\hline 住宅資産額(A) & 26,446 & 78,509 & 1,848 & 33,321 & 19,267 \\
\hline 耐久消費財等資産額(B) & 1,319 & 1,894 & 435 & 1,321 & 1,414 \\
\hline 貯蓄等現在高(C) & 17,668 & 28,181 & 8,152 & 18,502 & 10,816 \\
\hline 住宅のための負債現在高(D) & 1,717 & 4,026 & 57 & 1,952 & 5,092 \\
\hline その他の負債現在高(E) & 449 & 1,451 & 257 & 615 & 639 \\
\hline 負債現在高計(F＝D＋E) & 2,165 & 5,477 & 314 & 2,568 & 5,731 \\
\hline 金融資産額 $(\mathrm{G}=\mathrm{C}-\mathrm{F})$ & 15,502 & 22,704 & 7,838 & 15,934 & 5,085 \\
\hline 資産総額 $(A+B+G)$ & 43,268 & 103,107 & 10,121 & 50,575 & 25,767 \\
\hline
\end{tabular}

注） 1 ）高齢世帯は65歳以上の世帯員を含む世帯、その他世帯は 65 歳以上の世帯員を含まない世带。

2）住宅資産額は土地資産額を含む。

3）住宅資産額、耐久消費財等資産額は純資産額。

4) 耐久消費財等資産額はゴルフ会員権等の資産額を含む。

5 ）住宅のための負債は土地のための負債を含む。

6 ）不明を除く。 
世帯の負債は小規模である。そのなかでは持家（付加有り）世帯の 債務が多い。これは、所得の高い持家（付加有り）世帯が住宅ロー ンの債務を負う経済力をもち、資産価值のより高い住宅を取得する 場合が多いことを示唆する。しかし、持家（付加有り）世帯では、 負債が相対的に多いとはいえ、貯蓄等現在高が大きいために、金融 資産は多くなる。

続いて、住居費負担率を図 2 に示した。ここでの住居費負担率と は、住宅ローン返済額、家賃・地代、設備修繥・維持費の合計が可 処分所得に占める割合を指す。持家に住む高齢世帯では、住宅ロー ンの返済を終えたケースが多いことから、住居費負担率が低く、 $5 \%$ 未満の世帯が過半数を占める。高齢の持家世帯にとって、住宅 資産の保有に加え、低い住居費負担率は、暮らしの経済基盤を形成

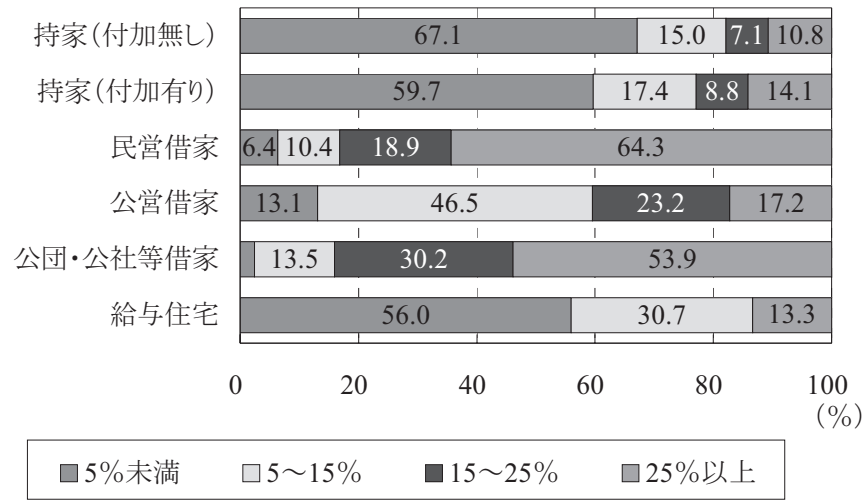

注）1）65歳以上の世帯員を含む世帯について集計。

2）住居費負担率は、1 1 月当たりの住宅ローン返済額、家賃 · 地代、設備修繥・維持費の合計が可処分所得に占める割合。

3 ）民営借家は借間を含む。

4）給与住宅は寮・寄宿舎を含む。5）不明を除く。

図 2 住宅所有形態別 高齢世帯の住居費負担率
寸る重要な要素である。持家世帯のなかでは、持家（付加有り）世 帯の住居費負担率が少し高い。これは、持家（付加有り）世帯での 住宅関連の負債が相対的に多いためである。住居費負担率が $15 \%$ 以 上の世帯は、持家（付加無し）では $17.9 \%$ 、持家（付加有り）では $22.9 \%$ であった。これに対し、借家世帯では、所得が低く、家賃支 出の必要性があるため、住居費負担が重い。借家世帯の中心を占め る民営借家世帯では、住居費負担がとくに重く、可処分所得の $25 \%$ 以上を住居費に支出している世帯が $64.3 \%$ に達する。公営借家では、 民営借家に比べて、住居費負担率が低く、25\%以上の世帯が $17.2 \%$ である。

持家の高齢世帯が保有する住宅資産額の平均值は高い。しかし、 このグループの住宅資産の規模は均質ではなく、階層化した状態を みせている。図 3 は、持家に住む高齢世帯に関して、現住宅と付加 住宅の資産額を、世帯年収と世帯類型に関連づけて示している。現 住宅資産額は、持家（付加無し）よりも持家（付加有り）において より大きい。現住宅資産額が 2000 万円未満、4000 万円以上の世帯 は、持家（付加無し）では 53.7\%、16.2\%、持家（付加有り）では $38.2 \% 、 29.6 \%$ であった。持家（付加有り）世帯は、現住宅に加え、 付加住宅の資産を保有する。現住宅に比べれば、付加住宅の資産額 は少なく、2000 万円未満が $59.9 \% 、 4000$ 万円以上が $21.8 \%$ である。 しかし、付加住宅資産の保有は持家（付加有り）世帯の住宅資産全 体をいっそう増やしている。

世帯年収と世帯類型は持家世帯の住宅資産額にどのように影響 するのか（図 3 )。先述のように、世帯年収の多い高齢世帯では持 家率がより高い。そして、持家世帯のグループのなかでは、より高 所得の世帯がより多量の住宅資産を保有する。現住宅資産額が 4000 万円以上の世帯は、持家（付加無し）の年収 300 万円未満、700 万 円以上では $12.9 \% 、 21.0 \%$ 、持家（付加有り）の 300 万円未満、 700 万円以上では $15.4 \% 、 38.6 \%$ となっている。持家（付加有り）世帯

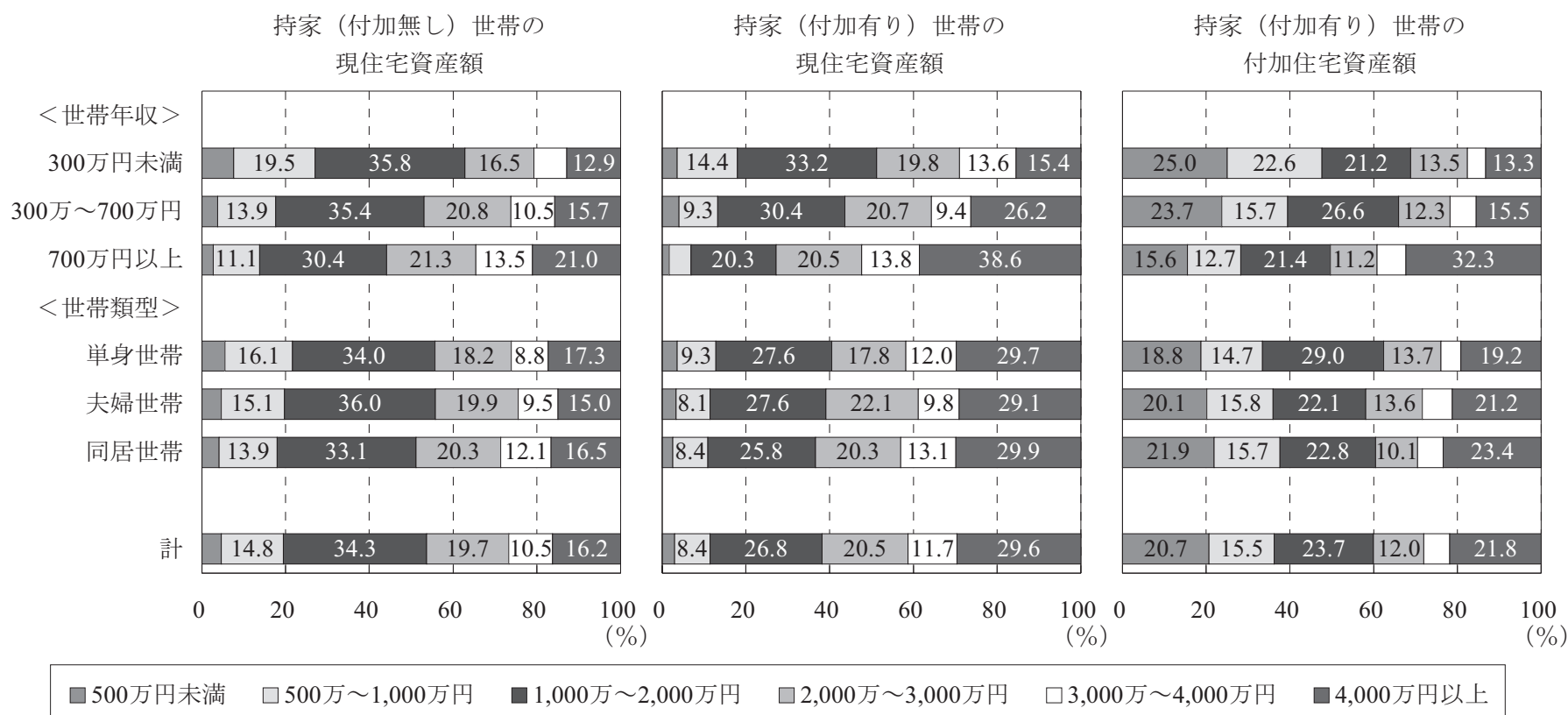

注） 1）65歳以上の世帯員を含む持家世帯について集計。 4 ）不明を除く。

2 ) 住宅資産額は土地資産額を含む。

3 ）住宅資産額は純資産額。

図 3 世帯年収・世帯類型別 高齢持家世帯の住宅資産額 
持家（付加無し）世帯

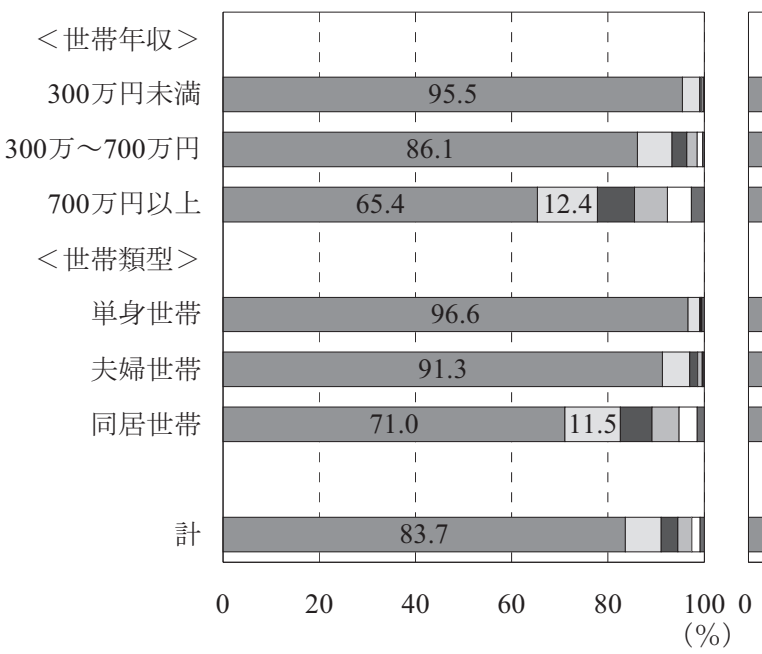

注）1）65歲以上の世帯員を含む持家世帯について集計。
持家（付加有り）世帯

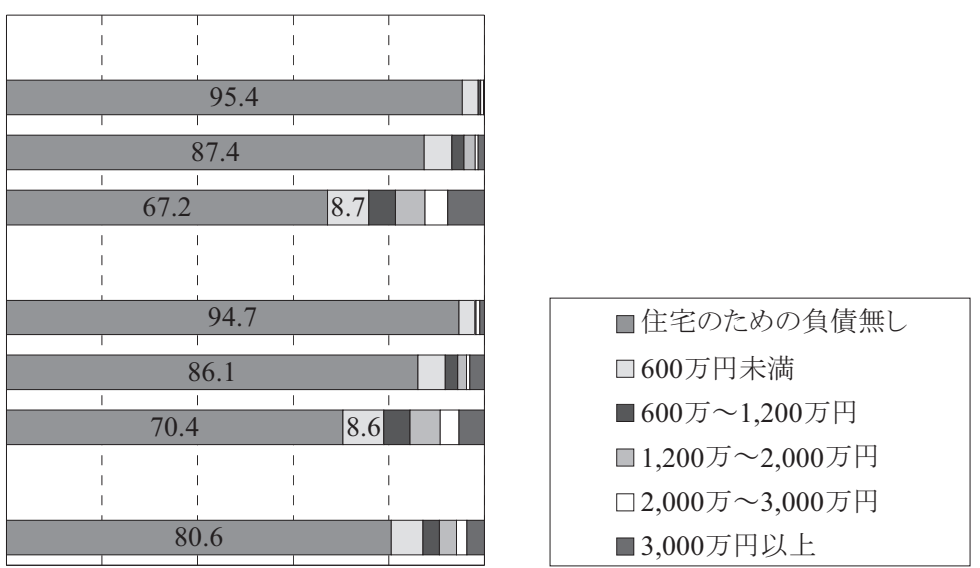

曰住宅のための負債無し

$\square 600$ 万円未満

600万〜 1,200 万円

$\square 1,200$ 万〜 2,000 万円

口3,000万円以上
$(\%)$

図 4 世帯年収・世帯類型別 高齢持家世帯の住宅のための負債現在高

のなかで付加住宅資産額が 4000 万円以上の世帯の割合をみると、 年収 300 万円未満では $13.3 \%$ であるのに比べ、 700 万円以上では $32.3 \%$ と高い。先にみたように、世帯類型は持家率に相関する。し かし、持家世帯のグループの範囲内では、世帯類型と住宅資産額の 関連性は弱い。世帯年収と世帯類型の双方は、持家率を左右する指 標となっているが、持家世帯のグループのなかでは、住宅資産の規 模に影響するのは世帯年収である。

住宅のための負債を世帯年収、世帯類型に関係づけて図 4 に表し た。持家の高齢世帯では、住宅関連の債務をもたない世帯が多く、 持家（付加無し）と持家（付加有り）の両者において約 8 割を占め る。住宅のための負債をもつグループのなかでは、持家（付加無し） 世帯よりも持家 (付加有り) 世帯の負債規模が大きい。世帯年収別、 世帯類型別に住宅関連の負債をみると、持家（付加無し）と持家（付 加有り) の両者に共通して、高年収世帯、同居世帯において負債を もつ世帯が相対的に多い。高所得のグループでは、その経済力の高 さを反映し、住宅のための債務を負う世帯が多くなる。同居世帯の グループでは、子世代が住宅ローンを組むケースが存在し、それが 住宅関連の負債をもつ世帯を増やしているとみられる。

\section{4. 付加住宅による家賃収入}

本稿では、付加住宅の存在に着目し、持家世帯を持家 (付加無し) 世帯と持家（付加有り）世帯に分け、両者の資産状況が大きく異な ることを示した。より高所得の世帯では付加住宅の所有率がより高 く、付加住宅をもつ世帯は、より多量の住宅資産と金融資産を保有 する。では、付加住宅は、その所有世帯の経済状態にどのように影 響するのか。付加住宅を賃貸住宅として供給する世帯は、そこから 家賃収入を得ることができる。ここでは、付加住宅による家賃収入 の実態をみる。

持家（付加有り）に住む高齢世帯のなかで、家賃収入（地代収入 を含む）を得ている世帯は 39.2\%を占める。付加住宅を貸貸住宅と して使っていないケースでは、その用途の中心は親族居住用である 注 12 。 持家（付加有り）世帯を家賃収入の有無によって分け、それ
表 3 高齢持家（付加有り）世帯の年間収入

\begin{tabular}{|c|c|c|}
\hline & $\begin{array}{c}\text { 家賃収入 } \\
\text { 無し } \\
\text { (千円) }\end{array}$ & $\begin{array}{c}\text { 家賃収入 } \\
\text { 有り } \\
\text { (千円) }\end{array}$ \\
\hline 勤め先収入 & 2,878 & 2,603 \\
\hline 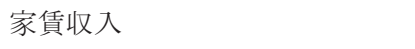 & - & 3,288 \\
\hline 家賃収入以外の事業・内職収入 & 687 & 835 \\
\hline 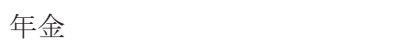 & 2,677 & 2,561 \\
\hline その他 & 238 & 317 \\
\hline 計 & 6,480 & 9,604 \\
\hline
\end{tabular}

注） 1）65歳以上の世帯員を含む持家（付加有り）世帯について 集計。2）家貨収入は地代収入を含む。

3 ）年金は、公的年金・恩給、企業年金・個人年金受取金。

$4 ）$ その他は、利子・配当金、親族などからの仕送り金、現物 消費の年間見積り額など。５）不明を除く。

ぞれの平均年収を表 3 に示した。平均年収は、家賃収入無しの世帯 での 648 万円に比べ、家賃収入有りの世帯では 960 万円と顕著に高 い。年収の中心は、勤め先収入、年金、及び家賃収入である。この うち勤め先収入と年金の額に関しては、家債収入有りの世帯と無し の世帯の間に大きな違いはみられない。換言すれば、家賃収入をも つ世帯では、家賃収入が年収全体を高める中心的な要素になってい る。家賃収入有りの世帯では、家賃年収の平均值は 329 万円で、こ れは年収全体の平均值の $34.3 \%$ に相当する。

次に、持家（付加有り）の高齢世帯に関して、家賃収入の水準を 世帯年収、世帯類型、及び付加住宅資産額に関連づけて図 5 に示し た。このデータが表すように、世帯年収が高いグループでは、家賃 収入を得ている世帯が多く、その家賃収入が多い。これは、高水準 の家債収入によって高所得が実現していることを表している。年収 300 万円未満では、家賃収入無しの世帯が $79.2 \%$ と多く、家賃収入 を得ている場合でも、その家賃収入は低い。これに対し、年収 700 万円以上では、家賃収入無しが $49.5 \%$ と相対的に少なく、200 万円 以上、400 万円以上の年間家賃収入をもつ世帯が $32.3 \% 、 21.3 \%$ を 占める。世帯類型と家賃収入の関連性は弱い。しかし、単身世帯で は、家賃収入を得ていない場合が $65.3 \%$ と少し多い。付加住宅の資 


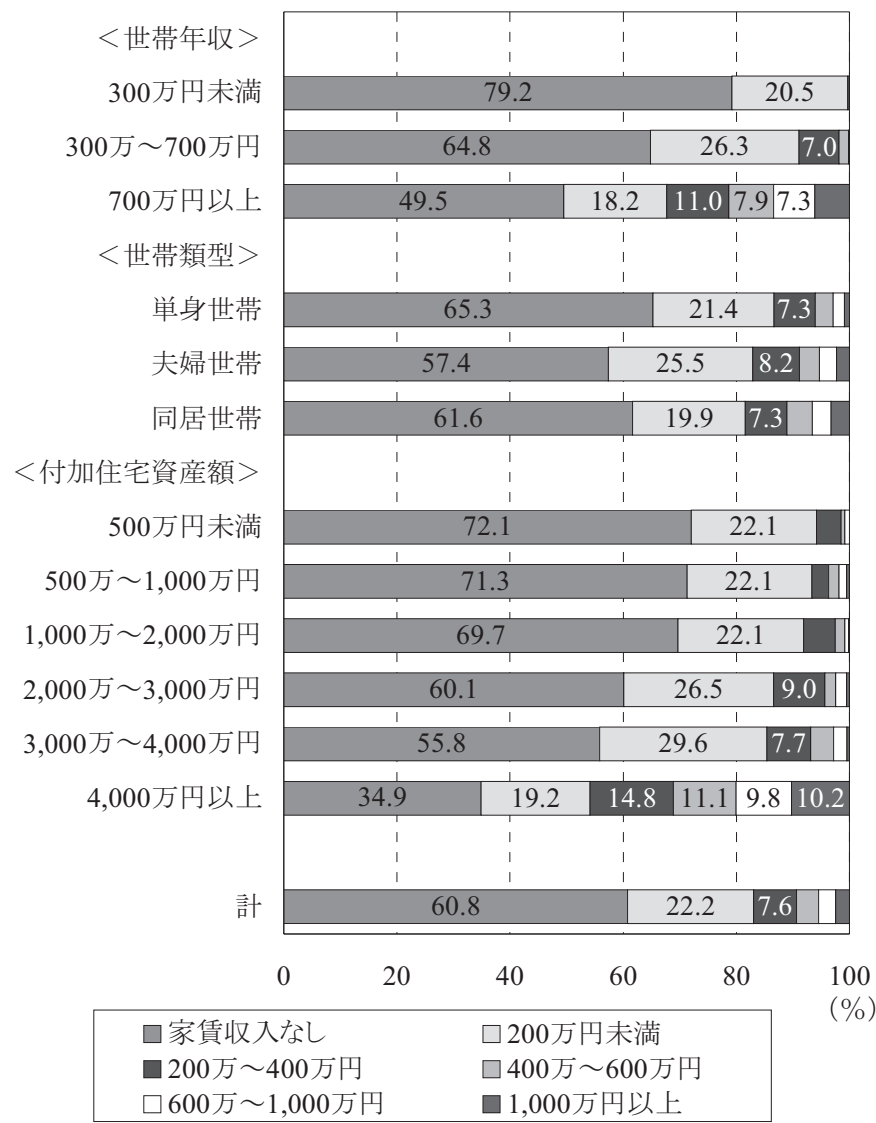

注）1）65歳以上の世帯員を含む持家（付加有り）世帯について 集計。2）家賃収入は地代収入を含む。

3 ）住宅資産額は土地資産額を含む。

4 ）住宅資産額は純資産額。5）不明を除く。

図 5 持家（付加有り）世帯の年間家貨収入

産額は家賃収入と明快に相関し、資産額が大きいほど年間家賃収入 が高い。付加住宅資産額が 2000 万円未満までの世帯では、家債収 入無しの割合が 7 割前後と高い。これに比べ、4000 万円以上の付加 住宅資産を保有する世帯では、家賃収入無しは $34.9 \%$ と少なく、年 間家賃収入 200 万円以上、 400 万円以上が $45.9 \% 、 31.1 \%$ を占める。

\section{5. 結論}

本稿では、全国消費実態調査のミクロデータを用い、高齢世帯に おける住宅資産保有の階層性を分析した。持家世帯については、付 加住宅を所有する世帯の存在に着目し、持家（付加無し）世帯と持 家（付加有り）世帯を異なるカテゴリーとして設定した。

分析の結果は、高齢世帯の住宅資産保有が顕著に階層化している 実態を示している。高齢世帯の平均像は、高い持家率、多量の住宅 資産と金融資産の保有、及び少量の債務によって特徴づけられる。 これが意味するのは、高䶜世帯の経済基盤における住宅所有の重要 性である。しかし、高齡者の住宅資産保有は均質ではない。本研究 では、持家が高齢世帯の住宅所有形態の中心を占めるなかで、持家 （付加無し）世帯と持家（付加有り）世帯が異質のグループを形成 することを明らかにした。この点は、持家世帯を付加住宅の有無に 応じて分節する分析手法の有効性を表している。より所得の高い世 帯では、持家（付加有り）世帯の割合がより高く、付加住宅を所有
する世帯では、住宅資産と金融資産がより大きい。持家（付加無し) と持家（付加有り）のそれぞれでは、より高所得の世帯がより大規 模な住宅資産をもつ。また、家顀収入をもつ持家（付加有り）世帯 では、その家賃収入が所得全体を高めるうえで重要な役割を果たし ている注 13)。

最後に、住宅政策の検討において、本稿で明らかとなった高齢世 帯の住宅資産保有の階層性がどのような含意をもつのかをみる。

第 1 に、高齢者の不動産活用の促進が政策課題とされてきた。そ の手法はリバースモーゲージに代表され、高齢者が保有する持家資 産のストックをキャッシュフローに転換しようとする発想にもと づく。この前提には、高龃者の多くが住宅資産を保有し、しかし低 い所得しかもっていない「ハウスリッチ・キャッシュプア」の状態 にあるという見方がある注 ${ }^{14)}$ 。リバースモーゲージの手法が立脚す るのは、「ハウスリッチ・キャッシュプア」である高需世帯の不動 産をキャッシュフローに転化し、高齢期の経済基盤を安定させよう とする考え方である。

しかし、住宅資産保有の階層性はリバースモーゲージの利用を阻 む一因になる注 15)。高齢世帯の平均像は「ハウスリッチ・キャッシ ユプア」である。しかし、このグループは均質ではなく、「ハウス リッチ・キャッシュリッチ」と「ハウスプア・キャッシュプア」の 世帯を多く含む。その含意は、キャッシュフローの必要性が大きい 低所得の高齢世帯は少量の住宅資産しか保有せず、「ハウスプア・ キャッシュプア」世帯はリバースモーゲージを利用するための条件 をもたない場合が多い、ということである。リバースモーゲージの あり方を検討するうえでは、住宅資産保有の階層化の実態をみるこ とが重要である。

これに関連して、第 2 に、付加住宅の賃貸住宅としての運用は、 不動産活用の一つの手法である。しかし、この手法は、高齢世帯の 経済状態をいっそう階層化する機能をもつ。本稿の分析が示したよ うに、付加住宅の保有率は高所得の世帯においてより高い。そして、 持家（付加有り）世帯のグループでは、所得のより高い世帯、付加 住宅資産のより多い世帯が家賃収入をより多く得ている。言い換え れば、付加住宅の賃貸住宅としての活用が可能なのは所得と資産を 豊富にもつ世帯に限られ、その活用は「ハウスリッチ・キャッシュ リッチ」世帯の収入をさらに増やす機能を有している。

第 3 に、住宅資産の相続が果たす役割を検討する必要がある。持 家ストックは、それを所有している「世帯」の資産を形成するだけ ではなく、世代を超える「家族」の資産として存在する。そして、 高齢世代の高い持家率、少子化の進展のもとで、子世代の住宅相続 の機会が増える可能性がある注 ${ }^{16)}$ 。本稿が依拠した全国消費実態調 查は、住宅相続の実態を把握しておらず、その役割を解明するには、 別途の研究が必要である。しかし、本稿では高齢世帯の住宅資産保 有が階層性をもつことを明らかにした。この点からすれば、住宅相 続は子世帯の資産形成に不均等な影響を与えると考えてよい。また、 住宅需要実態調查の 1998 年のデータを用いた既往研究によれば、 首都圈に住む借家世帯のなかで、相続可能性をもつ世帯は所得が高 く、高家䍹の広い住宅に住んでいるのに対し、相続可能性をもたな い世帯の多くは所得が低く、住宅事情を改善する展望をもっていな い注 ${ }^{17)}$ 。ここでは、住宅資産の階層性が世代を超えて受け継がれる 可能性が示唆されている。 
一方、相続された住宅ストックが有効に使われるとは限らない。 国土交通省が 2005 年に実施した「土地問題に関する国民の意識調 查」は「相続した住宅への対応」について設問した。その結果によ ると、「相続の予定はない」の回答率が $43 \%$ と最も高くなっている が、それ以外の回答では、「必要性に合致しているので、そこに住 む」が $11 \%$ と少ないのに対し、「必要性に合致していなければ、住 まないが、所有しておく」が $20 \%$ を占めた。同調查では「現住地以 外の土地を所有している」者のうち、「未利用地がある」と回答し た者について、未利用の理由を尋初ている。この結果によれば、「遺 産として相続したが、今のところ利用する予定がない」（34\%）の 回答率が最も高い。相続した住宅に住まない世帯がそのストックの 売却または賃貸によって利益を得るケースがある。しかし、相続不 動産が低い市場価值しかもたない場合がある。住宅相続が増えると 寸れば、それにともなって、有効利用の困難な住宅ストックが増大 することがありえる。

第 4 に、住宅政策の形成では、借家の居住条件の改善が重要な課 題である。高齢世帯の暮らしの経済基盤は、住宅所有形態に応じて 階層化し、顕著な違いをみせている。持家の高龃世帯に比較して、 借家の高齢世帯は、低い所得、少量の金融資産、高い住居費負担率 などの特徴をもつ。民営借家では住居費負担がとくに重い。高齢世 帯の多くは持家に住んでいる。しかし、単身世帯では借家率が相対 的に高い。そして、高龄層の持家率の高さが持続するかどうかは不 明確である。若い世代の持家率の低下、あるいは持家取得の遅れが 観察されてきた注 ${ }^{18)}$ 。この傾向は、高齢層における持家率の将来の 低下がありえることを示唆する。高い持家率が維持されるとしても、 高齢者人口の急速な増大によって、借家の高齢世帯の絶対数は増加 すると考えられる。高齢者のための借家事情の改善はすでに政策課 題とされ、そのための施策が始まっている注 19)。これをいっそう促 進する方向性が望まれる。

\section{注}

注1) 以下の記述については、Hirayama, Y.: The role of home ownership in Japan's aged society, Journal of Housing and the Built Environment, 25(1), 2010 (掲載決定)を参照。

注2)この住宅資産額は後述の純資産額で、土地資産額を含む。

注3) 文献 5)。

注4) 一橋大学経済研究所附属社会科学統計情報研究センターは、総務省統 計局統計調査部の依頼にもとづき、2004 年 11 月から 2008 年 10 月まで、 秘匿処理を行った政府統計ミクロデータの試行的提供を行っていた。本研 究は、これを利用して実施したものである。

注5) 実証研究として文献 1)2)8)9)11)などがある。

注6) 文献(1)では、高齢者の資産に関するアンケート調査の結果が示され、 相続と資産形成の関係の階層性が指摘されている。しかし、高歯世帯の住 宅資産に関して、系統的な統計分析を行った研究はみられない。

注7) 住宅・土地統計調査の 2003 年の結果によれば、高齢世帯の持家率は $83.8 \%$ 、借家率は $16.2 \%$ である。ここで使用している全国消費実態調査の 2004 年のデータでは、持家率が少し高く現れている。住宅・土地統計調査 は、全国消費実態調査に比べて、より多数のサンプルに関する調査である ことから、そのデータは実態により近いと考えられる。住宅所有形態に関 する両調査のデータが差をみせる点に留意しておく必要がある。

注8）文献 1)が指摘するように、遺産相続の遅れが高齢層に資産を集中する 結果をもたらしている。

注9）文献 13)、p.416 の集計表 95、p.424 の集計表 97 による。遺産相続が遅 れる傾向にあるという論旨を補強するため、ここでは文献 13)の調査の結 果に依拠した。この調査は、層化無作為抽出法(郵政公社支社別・人口規
模別)にもとづいて世帯主 20 歳以上 80 歳未満の全国の 1 万 8760 世帯を抽 出し、訪問留置法によって 3127 世帯 $(16.7 \%)$ から回答を得たものである。

注10)この点については文献 10)が参考になる。

注11)最初に述べたように、ここでの住宅資産は土地資産を含む。土地資産額 は宅地敷地面積に $1 \mathrm{~m}^{2}$ 当たり宅地単価（国土交通省地価公示または都道府 県地価調査の $1 \mathrm{~m}^{2}$ 当たり評価額を用いて推計した各調査単位区の $1 \mathrm{~m}^{2}$ 当 たり評価額）を乗じた数值で、借地の場合はこれに借地権割合（木造・防 火木造その他の場合は 0.5、鉄骨・鉄筋コンクリート造の場合は 0.6）を乗 じた数值である。

注12)住宅・土地統計調査の 2003 年の結果をもとに、付加住宅をもつ世帯主 65 歳以上の世帯に関して、付加住宅の用途別に世帯数をみると、貸家用の $41.5 \%$ が最も多く、次いで親族居住用の $36.0 \%$ が多い。このデータは、複 数の付加住宅をもつ世帯については、主な付加住宅の用途を表している。

注13) 前稿（文献 5)）では、所得階層によって住宅資産保有に差があることを 明らかにした。これに対し、本稿では、本文中に示したように、持家（付 加無し）と持家（付加有り）の資産保有実態が大きく異なり、両者が明白 に異なるグループを形成している点を新たに実証した。

注14) 文献 7)12)を参照。

注15)この点に関しては、文献 5)において論じた。また文献(12)を参照。リバ ースモーゲージ利用の停滞の要因として、高齢者の想定以上の長生き、不 動産価格の想定範囲を超える下落、想定以上の金利上昇などのリスク、及 び中古住宅市場の未発達などが知られている。しかし、住宅資産の階層性 もまたリバースモーゲージ利用の拡大を阻む要因である。

注16) 文献 6)7)を参照。

注17) 文献 9)。

注18) 文献 3)4)を参照。

注19)「高齢者の居住の安定確保に関する法律」の 2001 年制定などのもとで、 高齢者向け貨貸住宅の整備は重要な政策課題として位置づけられている。

\section{参考文献}

1) 荒川匡史: 高齢者保有資産の現状と相続: 高齢者内で循環する使われない 資産, Life Design Report, 150, pp.16-23, 2003

2) 荒川匡史：高齢者資産の流動化, Life Design Report, 154,pp.4-15, 2003

3) Forrest, R. and Hirayama, Y. (2009) The uneven impact of neo-liberalism on housing opportunities, International Journal of Urban and Regional Research, 33(4), pp.998-1013, 2009.

4) 平山洋介: 若年層の居住実態に関する個人単位分析, 日本建築学会計画系 論文集, 632,pp.2189-2195, 2008.10

5) 平山洋介: 住宅・土地資産形成の変容に関寸る実態分析, 日本建築学会計 画系論文集, 636, pp.431-438, 2009.2

6) Hirayama, Y.: Reshaping the housing system: home ownership as a catalyst for social transformation, Hirayama, Y. and Ronald, R. (eds.) Housing and Social Transition in Japan, London: Routledge, pp.15-46, 2007.

7) Izuhara, M.: Turning stock into cash flow: strategies using housing assets in an aging society, Hirayama, Y. and Ronald, R. (eds.) Housing and Social Transition in Japan, London: Routledge, pp.94-113, 2007.

8) 小池信子：増加する “相続予備軍”：平成 13 年度都市・住宅に関する市民 意識調査，調查研究期報, 134,pp.26-31, 2003

9) 園田眞理子: 首都圏における子育て世帯の住宅相続の可能性とそれに関連 する住宅需要の特性, 明治大学理工学部研究報告, 23, pp.23-30, 2000

10)鈴木晃: 独居老人の創出過程と住居移動, 日本生活学会編: 生活学 1987 , pp.152-196, 1987

11)高橋朋一：遺産動機と相続経験，郵政研究所月報, 16(3), pp.4-16, 2003

12)山田ちづ子：リバースモーゲージ：逆風からの離脱，日本不動産学会誌， 20(4), pp.100-107, 2007

13) 日本郵政公社郵政総合研究所：家計における金融資産選択等に関寸る調査 結果報告書,

(2009年 8 月 8 日原稿受理，2010年 2 月19日採用決定） 